\title{
Centenário de Nascimento do Professor Dr. Reynaldo Porchat.
}

Em maio de 1968, comemorou-se nesta Faculdade o centenário de nascimento de Reynaldo Porchat, que foi, por muitos anos, seu professor e Diretor.

Em sessão solene da Congregação, realizada no salão nobre, o Prof. Dr. Alexandre Augusto de C. Corrêa, titular da cátedra de Direito Romano, que pertenceu ao homenageado, falou sôbre sua vida e obra, analisando o notável Curso de Direito Romano, até hoje consultado por mestres $e$ alunos.

\section{Discurso do prof. Alexandre Augusto de Castro Corrêa}

Comemorar é solenisar a recordação d'algum acontecimento marcante, ou de personalidade notável na história nacional dum povo ou de suas instituições. Prendendo-se, como se prende, através da ação exercida por discípulos e mestres, aos magnos eventos de nossa história contemporânea, a Faculdade de Direito da Universidade de São Paulo relembra, habitualmente, a figura de seus grandes professôres, inclusive por ocasião da passagem do centenário de nascimento dos mesmos. Perpetua, assim, o culto de suas mais caras tradições e confirma ideais educativos e humanitários revendo-se naqueles, cuja pujança intelectual e alto senso cívico, lhe deram a própria razão de existir como escola e de confiar no futuro. 
Falar do Prof. Reynaldo Porchat é justamente exprimir, apontando seu exemplo, tudo quanto, professôres e discípulos, havemos por mais representativo da figura do jurisconsulto: o saber, a eloqüência e o civismo. Prestamos, pois, esta noite, solenemente e com alegria, homenagem justíssima à memória de Reynaldo Porchat.

Foi êle, sem qualquer restrição e na plenitude do têrmo, aquêle "ad agendum ad cavendum et ad respondendum peritus", de que fala Cícero definindo as funções e qualidades do jurisconsulto romano: sabia Porchat, como ninguém, orientar os clientes na condução das causas, era perito consumado na intrincada arte de redigir os atos jurídicos e distinguia-se, sobretudo, como autor de pareceres, cortando sempre o nó-górdio de complicadas questôes de direito.

Como professor de Direito Romano deixou o Prof. Porchat indelével lembrança na mente de seus inúmeros discípulos, todos êles elogiando abertamente as qualidades notórias do mestre: saber vasto, clareza perfeita d'idéias, eloqüência natural no expô-las, animada pela íntima convicção. Tão unânime é o juízo a êste respeito a ponto de me parecer suficiente falar de Reynaldo Porchat só como professor, deixando aos demais preclaros oradores desta noite o encargo de realçar as outras qualidades excepcionais desta figura tão bem dotada.

Meu pai, bacharel de 1912, foi aluno do Professor Porchat (junto com Henrique Bayma, Vicente Ráo, Guilherme de Almeida, Waldemar Ferreira e outros) e sempre manifestou estima e admiração pela personalidade de seu antecessor na cátedra de Direito Romano; Porchat, diz êle, era assíduo, impunha-se ao auditório pela palavra sempre eloqüente e fazia o curso guiando-se pelos fragmentos do Corpus Juris, citados solenemente aos discípulos no belo timbre de sua voz. E', nos exames, segundo consta, a contraprestação era escrupulosamente exigida aos estudantes, naqueles dias, "hélas"! mais familiarizados do que os de 
hoje com a língua de Papiniano. O Dr. Francisco Patti, ex-aluno do Prof. Porchat, contou-me, certa ocasião, pitoresca história, digna de ser aqui relembrada, pois ilustra de modo vívido o espontâneo sentimento humanístico do egrégio professor de Direito Romano. Iniciando uma aula sôbre a interpretação das leis perguntou "ex abrupto" o mestre: "Quem haverá, pelas ruas e praças desta cidade, ignorando o "Scire leges"? E, diante da provável hesitação dos ouvintes, prosseguiu serenamente: qual o cidadão, ainda o mais inculto, capaz de ignorar o sentido desta máxima (e lá vinha o célebre texto): "Scire leges, non est verba earum tenere, sed vim ac potestatem"? Queria, naturalmente, Porchat, mediante espirituoso recurso didático, transmitir aos alunos a convicção do caráter tão conforme à razão humana dos preceitos do Direito Romano, a ponto dêles serem acessíveis a qualquer pessoa de bom senso. $\mathrm{E}$ basta êste traço de sua mentalidade para situá-lo, desde logo, como Jurisconsulto!

Resumindo fecunda atividade de professor, legou-nos Porchat pequena obra prima, onde não sabemos o que mais admirar: se o poder de sintese ou a elegante clareza d'exposiçâo e d'estilo. Refiro-me ao Curso Elementar de Direito Romano. obra sempre citada e lembrada e também (coisa mais rara) lida com igual proveito até hoje por mestres, discípulos e estudiosos.

Peço licença, como parte da homenagem hoje prestada, para ler dedicatória de próprio punho, na bela caligrafia do Autor, oferecendo um exemplar do livro a meu pai.

"Prezado colega e amigo Prof. Alexandre Corrêa. Seguindo o seu amável conselho, mandei fazer uma segunda edição do meu curso elementar de Direito Romano. Como se incumbiu dessa tarefa apenas a editôra, saíu êste trabalho que aqui se vê de feitio caracteristicamente comercial. Mesmo assim, é prazer meu oferecer-lhe um exemplar, o 
que aqui faço em homenagem aos seus méritos e pedindo-lhe desculpa pela pouca finura da obra.

O colega e am..$^{\circ}$ admirador

$$
\text { Reynaldo Porchat". - 5.6.1937" }
$$

Passo agora, encerrando esta oração, a breve análise do Curso de Direito Romano do Prof. Porchat $\left(2 .^{\mathrm{a}}\right.$ edição de 1937).

Consta êle da História externa do Direito Romano, subdividida, como se sabe, clàssicamente em quatro períodos; na "Introdução", parte subseqüente, estudam-se em três capítulos as seguintes questões fundamentais: $D a$ importância do estudo do Direito Romano e da sua expansão pela Europa, Da influência do Direito Romano na legislação civil pátria, Direito Romano Justinianeu, o Corpus Juris Civilis. Vem depois a Parte Preliminar, central do livro, desdobrando-se nos seguintes capítulos: Idéias Gerais de Filosofia Jurídica, contendo a noção de direito, admitida pelo autor, sob a influência do positivismo da época, representado na Faculdade pelo colega de Porchat, o insigne Pedro Lessa; do Direito Subjetivo e Objetivo; do Direito Público e Privado; de Direito e Moral; do Sujeito e Objeto do Direito e da classificação das matérias do Direito Civil tratam os outros parágrafos dêste capítulo. Combinando Direito e Filosofia (as cadeiras de Direito Romano e Filosofia do Direito constavam, aliás, antigamente e segundo uso salutar, do primeiro ano do curso de bacharelado) utiliza o Autor, para as explicações filosóficas indispensáveis, vários textos e conceitos de Direito Romano. A parte dogmática principia no capítulo II. ${ }^{\circ}$ tratando das acepções do vocábulo "Jus" (§ 10), do conceito de Direito entre os romanos (§ 11), da distinção romana entre Direito e Moral ( $\S 12$ ) onde o Autor exatamente observa: "Mas, ao mesmo passo que a conheciam, observa-se no estudo do conjunto das disposições do direito 
romano que êles sentiam a necessidade de uma harmonia plena entre os preceitos da Moral e os do Direito" ( p. 112). Conheciam, por outro lado, com nitidez, os romanos, o critério da distinção entre Direito e Moral, tal como se depreende, entre outros, do conhecido "non omne quod licet honestum est". (Paulo, no D., 50, 17, 144). E conclui Porchat com acêrto: "... elementos existem que nos autorizam a concluir que os jurisconsultos descortinavam, embora não a exprimissem sempre em seus escritos, a distinção entre preceitos morais e juridicos".

São magistrais os $\S \S 13$ e 14, encerrando o capítulo e versando as interessantes questões dos "juris praecepta" e da classificação romana das matérias do direito privado. Refuta aí Porchat opinião inexata de Teixeira de Freitas, segundo o qual não haveria no texto de Gaio 1,8, (" $D e$ Juris Divisione"): "omne autem jus quo utimur vel ad personas pertinet vel ad res vel ad actiones", nenhum princípio classificador mostrando, com bons argumentos, como a divisão de Gaio, seguida por Justiniano e essencialmente também pelos Códigos modernos é na verdade sistemática.

Abre o capítulo III..$^{\circ}$ o parágrafo inicial $\left(n .^{\circ} 15\right)$ sôbre a Justiça, completado pelos outros dois sôbre a Eqüidade e a Jurisprudência. A respeito da Eqüidade merece ser realçada a parte na qual o Autor expõe "o conceito puro e filosófico da "aequitas" romana, distinta, como sabemos, da eqüidade grega. Contrapondo-a ao "Jus" mostra Porchat, com clareza admirável, a função da eqüidade romana, comparável sob vários aspectos, nos tempos modernos, à "equity" inglêsa. Ao tratar da Jurisprudência discute o Autor a controvertida definição de Ulpiano, reproduzida por Justiniano nas "Institutas" (1,1) e segundo a qual além de ciência do justo e do injusto a Jurisprudência é "divinarum atque humanarum rerum notitia". Aceita o mestre paulista a interpretação de Demangeat segundo o qual "para distinguir o justo do injusto, o moral do imoral é preciso partir dos altos problemas filosóficos que nos dão o conhecimento das cousas divinas e humanas" (p. 138). 
O capítulo IV intitulado, "Divisões do Direito" desdobra-se em 18 parágrafos tratando, mediante a exegese dos textos, das questões capitais sôbre "Jus publicum" e "Jus privatum", "Jus naturale, gentium et civile", "Jus commune et singulare" e sôbre fontes de produção do Direito. Página após página, com admirável equilíbrio, são os textos romanos hàbilmente utilizados para a exposição da mais pura doutrina.

Termina a parte preliminar pelo estudo, no capítulo V, da "Lei civil", incluindo, junto com as teorias do êrro de direito e de fato, expostas à luz das doutrinas de Donelo e Savigny a difícil teoria da interpretação das leis.

Rematando o capítulo com chave de ouro, oferece-nos o Autor sua reputadíssima explicação, em oito parágrafos, da "Retroatividade da Lei". Tão fortemente marcou nossas letras jurídicas a límpida exposição do egrégio romanista, a ponto de, ainda hoje, a mais de meio século de distância, desde a primeira publicação, ser ela lembrada por nossos melhores jurisconsultos, tal como sucedeu no último concurso de Direito Civil, aqui realizado no comêço dêste ano.

Terminada a brilhante e erudita Introdução encerra-se infelizmente o livro no primeiro capítulo da Parte Geral, subdividido em seis parágrafos, tratando da pessoa física, da capacidade jurídica e da "capitis deminutio". Ficou, pois, incompleta a obra, à semelhança da Sinfonia Inacabada de Schubert: os outros afazeres do advogado e do político roubaram ao professor valioso tempo.

Mesmo assim, porém e apesar de incompleto, o "Curso Elementar de Direito Romano" basta para assegurar a Reynaldo Porchat imorredoura fama como jurisconsulto e como romanista brasileiro. Quis a Providência fazê-lo brilhar também em outros cenários; graças ao próprio talento e mérito, ocupou o Professor Porchat a Diretoria desta Faculdade, sendo no Govêrno de Armando de Sales Olivelra o primeiro reitor de nossa Universidade; presidiu ainda o Conselho Superior d'Ensino; foi um dos fundadores da Academia Paulista de Letras. Senador estadual final- 
mente e membro conspicuo do Partido Democrático fêz o Professor Porchat, seu "cursus honorum", à semelhança do antigo cidadão romano. Amando a terra natal dedicou-se integralmente a ela, no pensamento e na ação. Junto com as virtudes cívicas, mostra-nos seu exemplo as culminâncias a que pode conduzir, em qualquer tempo, a cultura clássica e humanística, reforçada pela vontade constante e perpétua de bem fazer. 